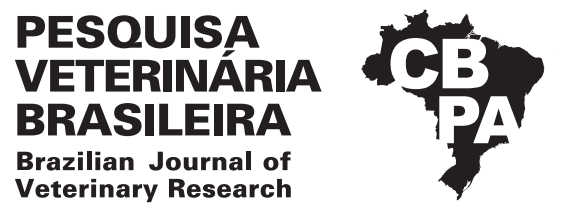

Pesq. Vet. Bras. 38(10):1885-1889, outubro 2018 DOI: 10.1590/1678-5150-PVB-5599

Original Article

Animais de Produção/Livestock Diseases

ISSN 0100-736X (Print)

ISSN 1678-5150 (Online)

\title{
Experimental poisoning by Brachiaria decumbens in rabbits ${ }^{1}$
}

\author{
Kiyoko U. Utiumi ${ }^{2 *}$, Adriana S. Albuquerque ${ }^{3}$, Alexandre S. Burque ${ }^{3}$, \\ Fernanda R. Souza ${ }^{3}$, Luciana Sonne ${ }^{4}$, Mary S. Varaschin ${ }^{3}$, Djeison L. Raymundo ${ }^{3}$ \\ and Ana Paula Peconick ${ }^{2}$
}

\begin{abstract}
Utiumi K.U., Albuquerque A.S., Burque A.S., Souza F.R., Sonne L., Varaschin M.S., Raymundo D.L. \& Peconick A.P. 2018. Experimental poisoning by Brachiaria decumbens in rabbits. Pesquisa Veterinária Brasileira 38(10):1885-1889. Setor de Medicina Veterinária Preventiva, Departamento de Medicina Veterinária, Universidade Federal de Lavras, Cx. Postal 3037, Lavras, MG 37200-000, Brazil. E-mail: ki_uemura@yahoo.com.br

Brachiaria spp. are important sources of forage for ruminants in Brazil, due to the easy cultivation, good resistance to drought, good adaptation to different soils and low maintenance cost. However, the ingestion of this grass has been related to photosensitization outbreaks in cattle and sheep with significant economic losses. The hepatotoxic effects related to the ingestion of grass are the formation of crystals and foamy macrophages due to the accumulation of toxic metabolites. The use of cattle and sheep in experiments involving the plant presents several obstacles in the ethical, economic and animal management. The objective of this study was to evaluate the sensitivity of rabbits as an experimental model for $B$. decumbens poisoning. Two experiments were carried out. In Experiment 1 four rabbits received the fresh plant in daily doses of 10, 20, 40 and 80g/kg body weight for 120 days. In Experiment 2 three rabbits received the fresh plant in amounts of $500 \mathrm{~g}$ daily with duration of 210 days. The animals of Experiment 1 showed no clinical signs and no macroscopic and microscopic changes characteristic of $B$. decumbens poisoning. In Experiment 2 the animals also showed no clinical signs or significant macroscopic alterations. Histological analysis showed isolated foamy macrophages or present in random groups of cells in the liver and mesenteric lymph nodes. Samples of liver and mesenteric lymph nodes of the rabbits of Experiment 2 were submitted to the lectin-histochemistry technique. The WGA, sWGA and RCA lectins showed reactivity in foamy macrophages in both organs. This is the first study of our knowledge that demonstrates histopathological lesions caused expetimentally by Brachiaria spp. in rabbits, demonstrating its potential as an animal model.
\end{abstract}

INDEX TERMS: Experimental model, hepatogenic photosensitization, lectin histochemistry, foamy macrophages, toxicoses.

RESUMO.- [Intoxicação experimental por Brachiaria decumbens em coelhos.] Brachiaria ssp. são importantes fontes de forragem para ruminantes no Brasil, devido ao fácil

\footnotetext{
${ }^{1}$ Received on January 31, 2018.

Accepted for publication on February 15, 2018.

${ }^{2}$ Setor de Medicina Veterinária Preventiva, Departamento de Medicina Veterinária, Universidade Federal de Lavras (UFLA), Cx. Postal 3037, Lavras, MG 37200-000, Brazil. *Corresponding author: ki_uemura@yahoo.com.br

${ }^{3}$ Setor de Patologia Veterinária, Departamento de Medicina Veterinária, Universidade Federal de Lavras (UFLA), Cx. Postal 3037, Lavras, MG 37200-000.

${ }^{4}$ Departamento de Patologia Clínica Veterinária, Faculdade de Veterinária, Universidade Federal do Rio Grande do Sul (UFRGS), Av. Bento Gonçalves 9090, Porto Alegre, RS 95320-000, Brazil.
}

cultivo, boa resistência a seca, boa adaptação a diferentes solos e baixo custo de manutenção. Entretanto, a ingestão desta gramínea está relacionada a surtos de fotossensibilização, em bovinos e ovinos, principalmente, ocasionando prejuízos econômicos significativos. Os efeitos hepatotóxicos relacionados à ingestão da gramínea são a formação de cristais e macrófagos espumosos causados pelo acúmulo de metabólitos tóxicos. A utilização de bovinos e ovinos em experimentos envolvendo a planta apresenta vários empecilhos, tanto no âmbito ético, econômico e no manejo dos animais. 0 objetivo do presente trabalho foi avaliar a sensibilidade de coelhos como modelo experimental para intoxicação por $B$. decumbens. No presente estudo foram realizados dois experimentos. 0 Experimento 
1 utilizou quatro coelhos que receberam a planta fresca em doses diárias de 10, 20, 40 e $80 \mathrm{~g} / \mathrm{Kg}$ de peso vivo durante 120 dias. 0 Experimento 2 utilizou três coelhos recebendo a planta fresca em quantidades de $500 \mathrm{~g}$ diárias por animal com duração de 210 dias. No Experimento 1, os animais não apresentaram sinais clínicos e nem alterações macroscópicas e microscópicas características de intoxicação por $B$. decumbens. No Experimento 2 os animais também não apresentaram sinais clínicos e alterações macroscópicas significativas. Na análise histológica observou-se presença de macrófagos espumosos isolados ou em grupos aleatórios de células no fígado e nos linfonodos mesentéricos. Amostras de fígado e linfonodos mesentéricos dos animais do Experimento 2 foram submetidos à técnica de lectino-histoquímica. As lectinas WGA, sWGA e RCA apresentaram reatividade em macrófagos espumosos nos dois órgãos. Este é o primeiro trabalho de nosso conhecimento que demonstra lesões histopatológicas por Brachiaria spp conduzido de forma experimental em coelhos, demonstrando seu potencial como modelo animal nesse campo de estudo.

TERMOS DE INDEXAÇÃO: Modelo experimental, fotossensibilização hepatógena, lectino-histoquímica, macrófago espumoso, toxicoses.

\section{INTRODUCTION}

Most of the pasture lands in Brazil correspond to Brachiaria spp. populations, mainly $B$. decumbens and $B$. brizantha, considered important forage sources for ruminants (Assis et al. 2003). However, annual outbreaks of photosensitization caused by the ingestion of these grasses are reported in several species of animals, especially cattle, sheep (Brum et al. 2007, Boabaid et al. 2011), goats and buffaloes, and eventually in equines (Barbosa et al. 2006, Riet-Correa et al. 2011, Miranda et al. 2016). Consequently, they cause significant economic losses, as well as a decrease in the productivity of Brazilian herds (Tokarnia et al. 2012).

The hepatotoxicity of Brachiaria is caused by protodioscin, a lithogenic steroidal saponin present in the plants (Brum et al. 2007, Riet-Correa et al. 2011, Miranda et al. 2016). Protodioscin also causes obstruction of bile ducts and the accumulation of phylloerythrin and consequent photosensitization with skin lesions (Lemos et al. 1997, Driemeier et al. 1999, Brum et al. 2007, Santos Junior 2008, Mustafa et al. 2012, Tokarnia et al. 2012). However, the exact amount of Brachiaria spp. that has to be ingested to cause photosensitization is still unknown (Mendonça et al. 2008).

Lectins are proteins or glycoproteins with one or more subunit binding sites that can reversibly bind to specific carbohydrate residues, agglutinate cells and/or precipitate polysaccharides or glycoproteins (Costa et al. 2013). Lectin-histochemistry can be used for the diagnosis of the hepatotoxicity of Brachiaria. The technique is efficient to detect carbohydrate residues that accumulate in foamy macrophages in bovine tissues that consume Brachiaria spp. (Costa et al. 2013).

Some animal species are used in experimental poisoning. Among them, sheep (Driemeier et al. 2002) present some advantages over cattle, including lower maintenance costs and easier management (Thompson et al. 1983). The use of other experimental models, such as rabbits, brings even more advantages because they are easy to manage and maintain, besides having a lower cost and faster reproductive cycle
(Thompson et al. 1983). The few experiments on Brachiaria spp. poisoning in rabbits conducted so far have demonstrated that the plant is palatable to the animals, but the studies did not successfully reproduced lesions and clinical signs (Souza et al. 2012, Facin et al. 2016).

The objective of this study was to create an experimental model using rabbits for experimental poisoning by $B$. decumbens resulting in typical hepatic lesions as seen in cattle and sheep.

\section{MATERIALS AND METHODS}

The experiment was approved by the Ethics Committee on Animal Use (ECAU) of UFLA under protocol number 078/2013. Sixty-day old male rabbits of the New Zealand breed were used in the study. The rabbits were housed in individual cages with water and commercial feed ad libitum. The plant access of Brachiaria decumbens Stapf cv Common was collected in the Department of Veterinary Medicine of the Federal University of Lavras (21 $13^{\circ} 52^{\prime \prime}$ S and $44^{\circ} 58^{\prime} 32^{\prime \prime} \mathrm{W}$ ) in morning hours. An exsiccate of the species was deposited in the University Herbarium for consultation.

Fresh plants were collected daily in the same field and offered to the animals; the non-consumed surplus was weighed and then discounted from the total value received. Two different experiments were carried out: in Experiment 1, four rabbits were kept in individual cages and given the amounts of $10 \mathrm{~g} / \mathrm{kg}$ for Rabbit $1 ; 20 \mathrm{~g} / \mathrm{kg}$ for Rabbit 2; $40 \mathrm{~g} / \mathrm{kg}$ for Rabbit 3; and $80 \mathrm{~g} / \mathrm{kg}$ for Rabbit 4 . All rabbits were fed with fresh $B$. decumbens. Rabbits were fed and monitored daily during 120 days; after that, they were euthanized and necropsied.

In Experiment 2, we used three rabbits. Each animal received $500 \mathrm{~g}$ of $B$. decumbens daily, the non-consumed surplus was weighed and discounted from the $500 \mathrm{~g}$ of food provided daily. This experiment lasted 210 days; after this time, the rabbits were euthanized and necropsied.

In both experiments, fragments of various organs were collected and fixed in $10 \%$ buffered formalin solution, routinely processed for histopathology with sections stained with hematoxylin and eosin (HE). The liver and lymph node fragments of animals from Experiment 2 were submitted to the lectin-histochemistry technique. The lectins used were Canavalia ensiformis agglutinin (Con-A), Dolichos biflorus agglutinin (DBA), Glicine max agglutinin (SBA), Arachis hypogaea agglutinin (PNA), Riccinus communis agglutinin-I (RCA-I), Ulex europaeus agglutinin-I (UEA-I), Triticum vulgaris agglutinin (WGA), Succinyl-WGA (sWGA), Griffonia (Bandeiraea) simplicifolia (GSL), Sophora japônica (SJA), Pisum sativum (PSA), Phaseolus vulgaris (PHA-L and PHA-E) and Lens culinaris or Lens esculenta (LCA). The histochemical lectin technique used was the same as that one reported by Boabaid et al. (2011).

\section{RESULTS}

The plant was identified as Brachiaria decumbens and an exsiccate was deposited for botanical confirmation and reproducibility of the present work.

In Experiment 1, the animals did not present clinical signs such as weight reduction, photosensitization or behavior change, and no macroscopic or microscopic alterations typical of $B$. decumbens poisoning were found. The daily toxic dose spontaneously ingested by each rabbit was $52 \mathrm{~g} /$ $\mathrm{kg}$ in Rabbit 1; 78g/kg in Rabbit 2; 61g/kg in Rabbit 3; and $133 \mathrm{~g} / \mathrm{kg}$ in Rabbit 4.

In Experiment 2, the animals showed no clinical signs such as weight reduction, photosensitization or behavior change 
and significant macroscopic alterations. In the histological analysis, we observed foamy macrophages isolated or in random groups of cells in the middle of the hepatic cords (Fig.1 and 2); hepatocyte swelling and vacuolization; individual hepatocyte necrosis; mild proliferation of bile ducts and proliferation of periportal connective tissue associated with periportal mononuclear infiltrates. In isolated mesenteric lymph nodes, isolated macrophages were seen in lymphatic sinuses (Fig.3) and follicular centers. The daily amount ingested by each rabbit in Experiment 2 was 203g/kg in Rabbit 5, 191g/kg in Rabbit 6, and 192g/kg in Rabbit 7.

Liver and mesenteric lymph node samples of the animals of Experiment 2 subjected to lectin-histochemistry are summarized in Table 1. The lectins sWGA (Fig.4), RCA-I, WGA, and GSL showed high reactivity and specificity for foam macrophages present in the liver of rabbits poisoned

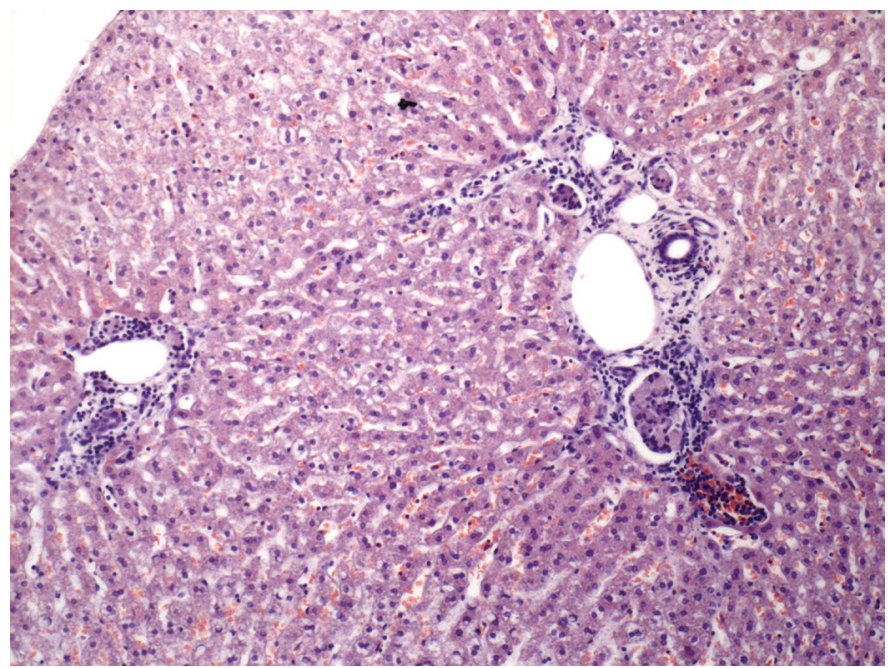

Fig.1. Rabbit liver experimentally poisoned by Brachiaria decumbens. Numerous isolated or clustered macrophages are observed. HE, obj.10x.

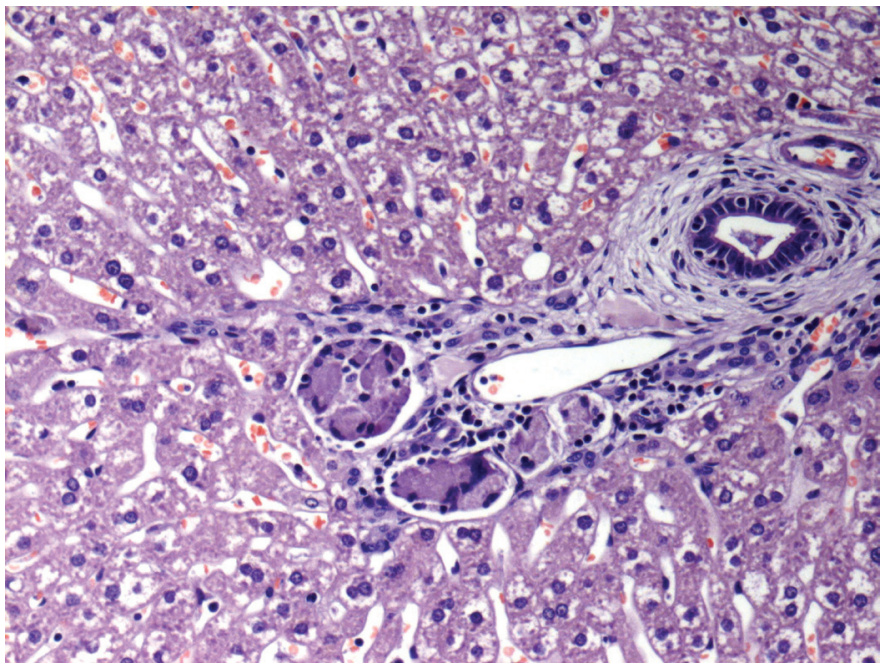

Fig.2. Rabbit liver experimentally poisoned by Brachiaria decumbens. Numerous isolated or clustered macrophages are observed. HE, obj.20x. by Brachiaria decumbens. The lectins Con-A, PNA and PHA-L showed moderate reactivity and specificity in liver foam macrophages. The foamy macrophages observed in mesenteric lymph nodes presented slight reactivity and specificity for sWGA (Fig.5), RCA-I, WGA, Con-A, PNA, PHA-L and PHA-E.

\section{DISCUSSION}

After the two experiments were carried out, it was possible to reproduce the hepatic and lymph node lesions in rabbits in Experiment 2. These lesions are similar to those described in cases of Brachiaria decumbens poisoning in sheep (Lemos et al. 1996) and cattle (Driemeier et al. 1998). The most characteristic injury caused by Brachiaria spp. poisoning is the presence of birefringent crystals and macrophages in bile ducts (Riet Correa et al. 2011), as wellas foamy

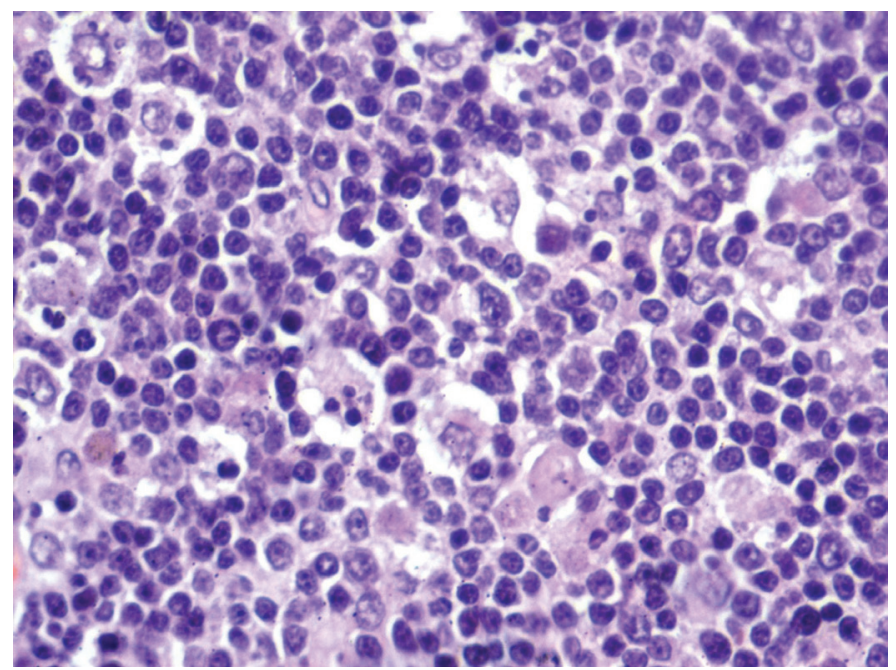

Fig.3. Rabbit mesenteric lymph node experimentally poisoned by Brachiaria decumbens. Isolated foamy macrophages are seen in lymphatic sinuses. HE, obj.40x.

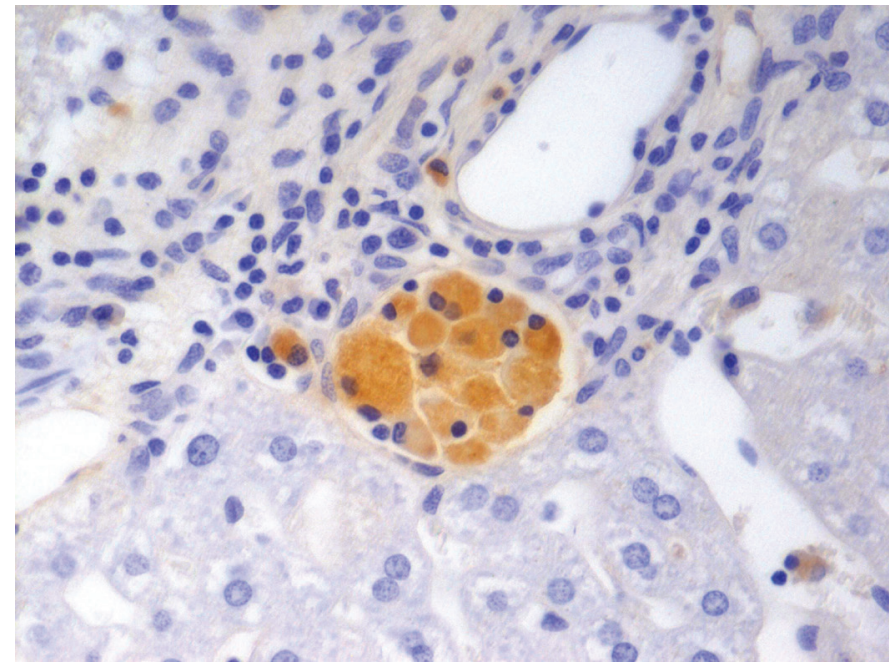

Fig.4. Rabbit liver experimentally poisoned by Brachiaria decumbens. Marked labeling for Succinyl-WGA (sWGA) in groups of foamy macrophages. Lectin-histochemistry, obj.40x. 
Table 1. Lectin-histochemical evaluation of the liver and mesenteric lymph node of rabbits experimentally poisoned with Brachiaria decumbens

\begin{tabular}{|c|c|c|c|c|c|c|c|c|}
\hline & Macrophages & Hepatocytes & Bile duct & $\begin{array}{l}\text { Bile duct } \\
\text { contents }\end{array}$ & $\begin{array}{l}\text { Bile duct } \\
\text { surface }\end{array}$ & Intimate vase & $\begin{array}{l}\text { Connective } \\
\text { tissue }\end{array}$ & Lymph node \\
\hline Con-A & $++^{*}$ & ++ & ++ & - & - & ++ & - & Macrophage + \\
\hline DBA & - & - & + & - & - & - & - & - \\
\hline SBA & + & + & - & - & - & - & - & - \\
\hline PNA & ++ & - & + & + & - & - & - & Macrophage + \\
\hline RCA-I & $++/+++$ & + & ++ & +++ & + & +++ & - & Macrophage + \\
\hline UEA-I & - & - & ++ & ++ & - & - & - & - \\
\hline WGA & $++/+++$ & - & - & + & - & + & ++ & Macrophage + \\
\hline sWGA & +++ & - & - & - & - & - & - & Macrophage + \\
\hline GSL & $++/+++$ & - & + & - & - & - & - & - \\
\hline SJA & - & - & - & - & - & - & - & - \\
\hline PSA & - & - & - & - & - & + & + & - \\
\hline PHA-L & $+/++$ & - & + & - & - & - & - & Macrophage + \\
\hline PHA-E & + & - & - & - & - & - & - & Macrophage + \\
\hline LCA & - & - & - & - & - & - & - & - \\
\hline
\end{tabular}

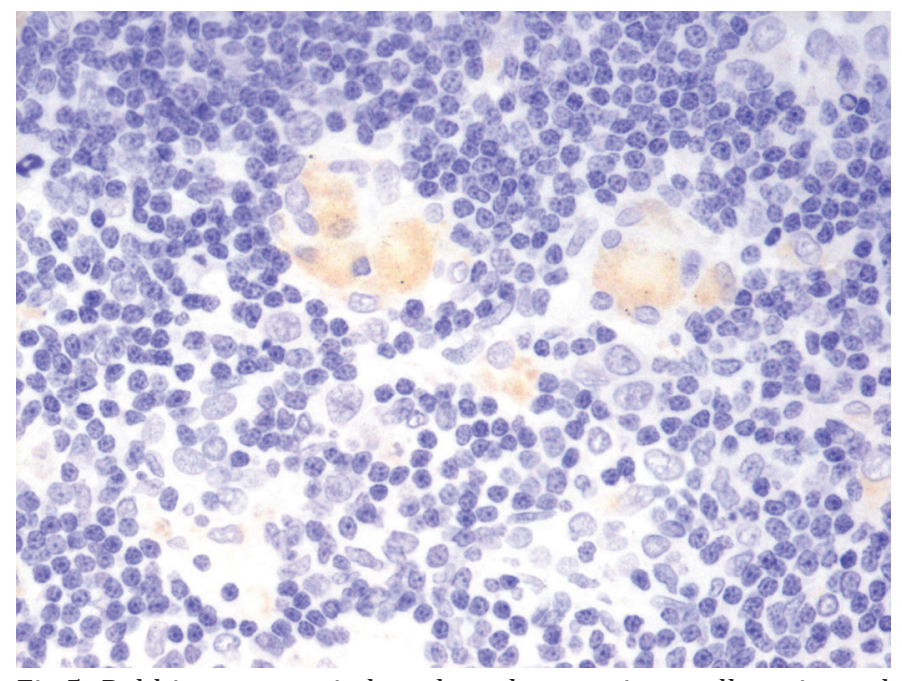

Fig.5. Rabbit mesenteric lymph node experimentally poisoned by Brachiaria decumbens. Light labeling for Succinyl-WGA (sWGA) in foamy macrophages isolated on lymphoid follicles. Lectin-histochemistry, obj.40x.

macrophages alone or in randomized groups in the liver (Lemos et al. 1996, Driemeier et al. 1998, Riet-Correa et al. 2010). The presence of foamy macrophages in the liver, either alone or in random groups, was the most consistent finding of $B$. decumbens poisoning in rabbits of Experiment 2; however, in no animal birefringent crystals in bile ducts and macrophages were present, which is also described in other cases (Riet-Correa et al. 2010, Miranda et al. 2016). The presence of foamy macrophages in mesenteric lymph nodes is described in cases of poisoning in different ruminant species, both in lymphatic sinuses (Driemeier et al. 1998, Riet-Correa et al. 2010) and follicular centers (Boabaid et al. 2011, Miranda et al. 2016).
Experiment 1 demonstrated that daily toxic doses of up to $133 \mathrm{~g} / \mathrm{kg}$ of body weight for up to 120 days are not enough to cause hepatic lesions by Brachiaria decumbens poisoning. These findings are similar to those of another study using rabbits as an experimental model for disease which also demonstrated that lower doses and times did not cause clinical signs or lesions in rabbits (Facin et al. 2016). Experiment 2 demonstrated that daily toxic doses of $190 \mathrm{~g} / \mathrm{kg}$ during 210 days were enough to induce hepatic lesions by $B$. decumbens poisoning.

The lectin-histochemistry labeling presented by rabbits poisoned by B. decumbens showed a pattern similar to other species. The marked labeling of foamy macrophages in the liver was seen mainly in the lectins RCA-I, WGA, sWGA and GSL, which was also observed in sheep (Boabaid et al. 2011) and buffaloes (Miranda et al. 2016). Slight labeling in the lectins Con-A-1, PNA and PHA-L was observed in the present study, as well as reported in buffaloes (Miranda et al. 2016) and ovines with more intensity (Boabaid et al. 2011, Costa et al. 2013). In the case of foamy macrophages in lymph nodes, the lectins Con-A, PNA, WGA, sWGA, PHA-L and PHA-E were slightly labeled in rabbits; while in sheep and buffaloes they had a moderate to intense labeling (Boabaid et al. 2011, Miranda et al. 2016).

There is only one reference in the literature of hepatic lesions containing foamy macrophages, but this occurred in a natural outbreak of $B$. decumbens poisoning in rabbits kept on pasture (Souza et al. 2012). The present experimental study, as well as another similar study (Facin et al. 2016), showed that rabbits present a higher resistance to $B$. decumbens poisoning because doses up to $130 \mathrm{~g} / \mathrm{kg}$ during a period of ingestion of up to 120 days were not enough to induce lesions in the liver or lymph nodes of the animals. Although lesions were observed in animals that ate doses of $190 \mathrm{~g} / \mathrm{kg}$ over a period of 210 days, it was not possible to define the toxic dose and minimum period necessary to observe hepatic lesions of poisoning.

The observation of development of lesions in the liver and lymph nodes in rabbits brings advances, both ethically and 
economically, due to the possibility to replace other species, such as cattle and sheep, used in the study of $B$. decumbens poisoning. Furthermore, it is possible to advance the knowledge on the pathogenesis of the disease, highlighting the main determinants involved in plant poisoning, and also the better understanding of the effects of poisoning in horses because there are anatomical similarities of the digestive tract between the two species.

\section{CONCLUSION}

The results demonstrate that it is possible to use rabbits as models for studies of experimental poisoning by Brachiaria decumbens; it was possible to reproduce liver lesions with the presence of foamy macrophages and also in lymph nodes, similar to lesions found in cattle, sheep and horses.

Acknowledgements.- To PhD student Wanderley Bittencourt from the Department of Agriculture, Federal University of Lavras, for the identification and classification of the plant. To Mv. Marcele Bettim Bandinelli, Department of Veterinary Clinical Pathology, Federal University of Rio Grande do Sul, for assistance in lectin-histochemistry. To the Coordination for the Improvement of Higher Education Personnel (CAPES), the Foundation for Research Support of the State of Minas Gerais (FAPEMIG), and the National Council for Scientific and Technological Development (CNPq), for the scholarships of scientific initiation and post-graduation, and for financial support to the study.

\section{REFERENCES}

Assis G.M.L., Euclydes R.F., Cruz C.D. \& Valle C.B. 2003. Discriminação de espécies de Brachiaria baseada em diferentes grupos de caracteres morfológicos. Revta Bras. Zootec. 32(3):576-584. <http://dx.doi.org/10.1590/S151635982003000300009>

Barbosa J.D., Oliveira C.M.C., Tokarnia C.H. \& Peixoto P.V. 2006. Fotossensibilização hepatógena em equinos pela ingestão de Brachiaria humidicola (Gramineae) no Estado do Pará. Pesq. Vet. Bras. 26(3):147-153. <http://dx.doi. org/10.1590/S0100-736X2006000300003>

Boabaid F.M., Antoniassi N.A.B., Pescador C.A., Souza M.A., Gasparetto N.D., Cruz C.E.F., Bezerra Júnior P.S., Driemeier D. \& Colodel E.M. 2011. Lectin histochemistry on sections of liver and a hepatic lymph nodes from sheep grazing on Brachiaria spp., p.124-128. In: Riet-Correa F., Pfister J., Schild A.L., Wierenga T. (Eds), Poysoning Plants, Mycotoxins and Related Toxins. CAB International, London. <http://dx.doi.org/10.1079/978184 5938338.0124>.

Brum K.B., Haraguchi M., Lemos R.A.A., Riet-Correa F. \& Fioravanti M.C.S. 2007. Crystal-associated cholangyopathy in sheep grazing Brachiaria decumbens containing the saponin protodioscin. Pesq. Vet. Bras. 27(1):39-42.<http:// dx.doi.org/10.1590/S0100-736X2007000100007>

Costa S.Z.R., Nespoli P.B., Bezerra Júnior P.S., Nogueira V.A., Driemeier D., Boabaid F.M., Peixoto P.V., Armién A.M. \& França T.N. 2013. Avaliação lectino-histoquímica de fígado e rim de ovinos com fotossensibilização causada por Brachiaria decumbens. Pesq. Vet. Bras. 33(8):955-962. <http:// dx.doi.org/10.1590/S0100-736X2013000800001>

Driemeier D., Barros S.S., Peixoto P.V., Tokarnia C.H., Döbereiner J. \& Brito M.F. 1998. Estudo histológico, histoquímico e ultra-estrutural de fígados e linfonodos bovinos com presença de macrófagos espumosos ("foam cells"). Pesq. Vet. Bras. 18(1):29-34. <http://dx.doi.org/10.1590/S0100736X1998000100005>
Driemeier D., Dobereiner J., Peixoto P.V. \& Brito M.F. 1999. Relação entre macrófagos espumosos ("foam cells") no fígado de bovinos e ingestão de Brachiaria spp no Brasil. Pesq. Vet. Bras. 19(2):79-83. <http://dx.doi. org/10.1590/S0100-736X1999000200005>

Driemeier D., Colodel E.M., Seitz A.L., Barros S.S. \& Cruz E.F. 2002. Study of experimentally induced lesions in sheep by grazing Brachiaria decumbens. Toxicon 40(7):1027-1031. <http://dx.doi.org/10.1016/ S0041-0101(01)00276-8><PMid:12076657>

Facin T.C., Pupin R.C., Leal P.V., Santos A.C., Lima S.C., Ferreira V.B.N., Garcez W.S. \& Lemos R.A.A. 2016. Evaluation of the toxicity of Brachiaria decumbens in rabbits. Vet. Bras. Med. Vet. 38(2):143-146.

Lemos R.A.A., Salvador S.C. \& Nakazato L. 1997. Photosensitization and crystal associated cholangiohepatophaty in cattle grazing Brachiaria decumbens in Brazil. Vet. Hum.Toxicol. 39(6):376-377. <PMid:9397512>

Lemos R.A.A., Ferreira L.C.L., Silva S.M., Nakazato L. \& Salvador S.C. 1996. Fotossensibilização e colangiopatia associada a cristais em ovinos em pastagens com Brachiaria decumbens. Ciência Rural 26(1):109-113. <http://dx.doi.org/10.1590/S0103-84781996000100020>

Mendonça F.S., Camargo L.M., Freitas S.H., Dória R.G.S., Baratella-Evêncio L. \& Evêncio-Neto J. 2008. Aspectos clínicos e patológicos de um surto de fotossensibilização hepatógena em ovinos pela ingestão de Brachiaria decumbens (Graminae) no município de Cuiabá, Mato Grosso. Ciênc. Anim. Bras. 9(4):1034-1041.

Miranda I.C., Riet-Correa G., Oliveira Júnior C.A., Riet-Correa B., Peixoto P.V., Costa S.Z.R., d'Avila M.S., Cid G.C. \& França T.N. 2016. Avaliação lectinohistoquímica de fígado e linfonodo mesentérico de búfalos mantidos em pastagens de Brachiaria spp. Pesq. Vet. Bras. 36(9):798-804. <http:// dx.doi.org/10.1590/s0100-736x2016000900002>

Mustafa V.S., Moscardini A.R.C., Borges J.R.J., Reckziegel G.C., Riet-Correa F. \& Castro M.B. 2012. Intoxicação natural por Brachiaria spp. em ovinos no Brasil Central. Pesq. Vet. Bras. 32(12):1272-1280. <http://dx.doi. org/10.1590/S0100-736X2012001200010>

Riet-Correa B., Riet-Correa F., Oliveira Junior C.A., Duarte V.C. \& Riet-Correa G. 2010. Alterações histológicas em fígados e linfonodos de búfalos (Bubalus bubalis) mantidos em pastagens de Brachiaria spp. Pesq. Vet. Bras. 30(9):705-711. <http://dx.doi.org/10.1590/S0100-736X2010000900001>

Riet-Correa B., Castro M.B., Lemos R.A.A., Riet-Correa G., Mustafa V. \& Riet-Correa F. 2011. Brachiaria spp. Poisoning of ruminants in Brazil. Pesq. Vet. Bras 31(3):183-192. <http://dx.doi.org/10.1590/S0100-736X2011000300001>

Santos Junior H.L. 2008. Estudo da toxicidade de diferentes estágios de crescimento da Brachiaria decumbens em ovinos. Dissertação de Mestrado, Faculdade de Agronomia e Medicina Veterinária, Universidade de Brasília, DF. 65 p.

Souza R.I.C., Santos A.C., Faccin T.C., Lima S.C., Pupin R.C., Leal P.V. \& Lemos R.A.A. 2012. Achados incidentais em fígados de coelhos alimentados com Brachiaria decumbens. Anais VII ENDIVET, Porto Alegre, RS. 115p.

Thompson K.G., Jones D.H., Sutherland R.J., Camp B.J. \& Bowers D.E. 1983. Sporodesmin toxicity in rabbits: biochemical and morphological changes. J. Comp. Pathol. 93(2):319-329. <http://dx.doi.org/10.1016/00219975(83)90018-X><PMid:6134760>

Tokarnia C.H., Brito M.F., Barbosa J.D., Peixoto P.V. \& Döbereiner J. 2012 Plantas Tóxicas do Brasil para Animais de Produção. 2ª ed. Helianthus, Rio de Janeiro, p.323-335. 